\title{
ADDRESSING SERVICE QUALITY ISSUES IN HIGHER EDUCATION: THE EDUCATIONAL ENVIRONMENT EVALUATION FROM THE STUDENTS' PERSPECTIVE
}

\author{
Yulia Stukalina \\ Transport and Telecommunication Institute, Lomonosova street 1, LV-1019 Riga, Latvia \\ E-mail:alina_s@tsi.lv
}

Received 15 January 2011; accepted 17 June 2011

\begin{abstract}
Concern about the quality of higher education is on the rise in Europe. To provide quality enhancement of the educational environment higher education institutions should create and implement a strategy for their higher school improvement - a long-term action plan aimed at achieving organisational goals, which includes a) the management of the organisational units as interconnected and interdependent entities; b) the engagement of students in quality assurance activities as enthusiastic and responsible academic community members. This paper discusses the importance of using regular educational environment evaluation, which involves students' indirect participation in decision-making, as one of the most essential quality assurance activities associated with higher school improvement. It also emphasizes the significance of measuring student satisfaction in education, student satisfaction and student motivation being the result of student interactions with the educational environment in the form of students' perceptions of the educational services.
\end{abstract}

Keywords: quality assurance in higher education, educational environment evaluation, student surveys, student satisfaction, student motivation.

Reference to this paper should be made as follows: Stukalina, Y. 2012. Addressing service quality issues in higher education: the educational environment evaluation from the students' perspective, Technological and Economic Development of Economy 18(1): 84-98.

JEL Classification: I23, I29.

\section{Introduction}

Globalization and the accompanied changes in all spheres of modern life call for "improving the quality of student learning and the learning experience - the pressures for change in higher education are evident on all sides, and the pace of change is ever increasing" (McRoy, Gibbs 2009). In the meantime, managing for quality is a very important aspect in the context of 
creating the European Higher Education Area that is expected to provide citizens of the European Union with broad access to high-quality higher education (Bologna declaration... 1999).

Programs intended for modernization of higher education must include a strategy for the continuous improvement of the quality of the educational services provided by higher education institutions. Concern about the quality of higher education is on the rise in Europe. As stated in Standards and Guidelines for Quality Assurance in the European Higher Education Area (2005), "learning resources and other support mechanisms should be accessible to students, designed with their needs in mind and responsive to feedback from those who use the services provided". Students, being consumers of educational services (Brochado 2009), along with other university stakeholders, should be engaged in the process of school improvement (Standards and Guidelines for Quality Assurance in the European Higher Education Area 2005) - that is quality enhancement of the educational environment.

There is a necessity to link the needs of the customer with service functions in the framework of creating a student-centred educational environment. To provide qualitative changes in the educational environment that motivates students for further studies is critical for the successful performance of an educational organization (Stukalina 2010a). As said by Brochado (2009), higher education institutions must make sure that all services encounters are managed to enhance consumer perceived quality; it is necessary to monitor the quality of the services they provide with the aim to introduce continuous improvements. Student satisfaction with the educational services may be regarded as a significant quality factor in educational settings (Postema, Markham 2001). Monitoring the quality of educational services may include regular educational environment evaluation, student feedback being a crucial contribution to the process of managing the learner-centered educational environment.

This paper discusses the importance of using regular educational environment evaluation, which involves students' indirect participation in decision-making, as one of the most essential quality assurance activities associated with higher school improvement. It also emphasizes the significance of measuring student satisfaction in education, student satisfaction and student motivation being the result of student interactions with the educational environment in the form of students' perceptions of the educational services.

\section{Evaluation in education}

According to Diamantis and Benos (2007), institutional evaluation is one of the most modern and appealing issues of higher education systems. As stated in the Research Methods Knowledge Base (2010), evaluation - "the systematic assessment of the worth or merit of some object" - is regarded as a methodological area directly linked to, however different from more traditional social research. On the one hand, it makes use of some similar methodologies applied in traditional social research; on the other hand, evaluation takes place in a political and organizational context and it calls for "group skills, management ability, political dexterity, sensitivity to multiple stakeholders" (ibid).

There are numerous analogous definitions and explanations of evaluation in education. Rossi and Freeman (1993) define evaluation as "the systematic application of social research procedures for assessing the conceptualization, design, implementation, and 
utility of ... programs". As defined by the American Evaluation Association (the Research Methods Knowlege Base: Web source), evaluation involves "assessing the strengths and weaknesses of programs, policies, personnel, products, and organizations to improve their effectiveness". Therefore, evaluation in education can be characterized as the organized collection and analysis of data to provide constructive feedback about different aspects of the educational environment, which is necessary to support decision-making within an educational institution.

We view the educational environment evaluation as the systematic organized collection and analysis of data in the framework of social research procedures, which are necessary to make decisions aimed at creating an educational environment conducive to learning; an efficient managerial instrument for monitoring the quality of the educational services provided by a higher education institution. Through regular educational environment evaluation administrators determine how well they are offering educational services. There exist a variety of evaluation strategies or perspectives on evaluation (The Research Methods Knowledge Base: Web source):

- Scientific-experimental models, which involve methods from the sciences, especially the social sciences, and which prioritize on the desirability of impartiality, accuracy, objectivity and the validity of the information generated.

- Management-oriented systems models (for example, PERT - the Program Evaluation and Review Technique), which emphasize comprehensiveness in evaluation and use evaluation in a larger framework of organizational activities.

- Qualitative/anthropological models, which stress the significance of observation, the need to keep the "phenomenological quality of the evaluation context, the value of subjective human interpretation in the evaluation process".

- Participant-oriented models, which put emphasis on the central importance of the evaluation participants, especially customers; they are consumer-oriented evaluation systems.

We think that the holistic approach to the educational environment evaluation presupposes employing elements of different evaluation strategies:

- The educational environment evaluation should be performed in a larger framework of organizational activities; according to Diamantis and Benos (2007), education administrators are gradually more using quality assurance techniques in the management of schools and universities.

- For the educational environment evaluation we may use different methods from the social sciences.

- From the phenomenological view (Greenfield 2004), we have to take into account the value of subjective human interpretation in the educational environment evaluation process.

- Since our efforts are aimed at creating the learner-centered educational environment, student-oriented approach seems to be rather helpful.

Therefore, we assume that the educational environment evaluation is supposed to be closely associated with assessing quality and value; it should be considered in the context of higher school improvement. 


\section{Educational environment evaluation in the context of higher school improvement}

Educational reforms in Europe are aimed at school improvement and educational quality enhancement. Brauckmann and Pashiardis (2010) call them "competitiveness-driven" educational reforms, and they characterise them as an "evaluation-based steering concept that represents a combination of a) decentralization of decision-making; b) use of education standards; c) attempts to set up monitoring systems; d) evaluations, both external and internal".

In the context of higher school improvement, education managers should perform regular educational environment evaluation, student feedback being an essential contribution to the process of managing the learner-centred educational environment. This way we may ensure that the educational organisation has ample and appropriate resources necessary for supporting sustainable learning process in general, as well as a definite study programme/ subject in particular.

The report prepared by the European Association for Quality Assurance in Higher Education (ENQA) provides a few recommendations on standards and guidelines for quality assurance in higher education, the term "quality assurance" referring to such processes as evaluation, accreditation and audit (Standards and Guidelines for Quality Assurance in the European Higher Education Area 2005). European standards for quality assurance in higher education incorporate standards for both internal quality assurance within higher education institutions and the external quality assurance of higher education. Among other things these standards include policy and procedures for quality assurance that should have a formal status and acknowledge a role for students and other stakeholders (ibid). Assurance of quality in higher education is a "process of establishing stakeholder confidence that provision (input, process and outcomes) fulfils expectations or measures up to threshold minimum requirements" (Harvey 2004, 2009).

We presume that to provide quality enhancement of the educational environment, higher education institutions should create and implement a strategy for the continuous enhancement of quality, i.e. a strategy for a higher school improvement - a long-term action plan aimed at achieving organisational goals, which includes

a) the management of the organisational units as interconnected and interdependent entities;

b) the engagement of students in quality assurance activities as enthusiastic and responsible academic community members, the educational environment evaluation with emphasis on collecting student feedback being an essential quality assurance activity.

According to Ehlers (2009), the holistic understanding of educational quality takes as fact that quality enhancement of an educational organisation should be focused on "change more than on control". Fiddler (2002) points out that school improvement includes providing change as in learning conditions as in the related internal conditions. Learning conditions are associated with the internal educational environment of an educational organisation comprising a wide range of resources. The resources vary from physical resources (libraries 
or computing facilities, etc.) to human support in the form of teachers, tutors, counsellors, and other advisers (Standards and Guidelines for Quality Assurance in the European Higher Education Area 2005).

Diversity of organizational resources is an essential characteristic of contemporary educational environment. A holistic understanding of the educational environment would help us be aware of complex relationships within modern educational organization. The management of the educational environment resources presumes that education managers, during their everyday interactions with the educational environment, coordinate and redistribute an arrangement of integrated educational environment resources: tangible, intangible and semi-tangible (Stukalina 2008).

The educational environment can also be considered as a community of people - the intellectual capital holders - united by collective objectives and joint interests. Understanding of the educational environment as a complex supersystem demands creating new standards of educational management practices in the context of higher school improvement. Education managers should ensure that their institution have sufficient and proper resources necessary for supporting sustainable learning process. These resources represent both the material and intellectual potential of an organization, the intellectual capital being the most valuable assets of an academic community.

\section{Educational environment evaluation in the framework of integrated management procedures}

We suppose that from the holistic approach to managing the educational environment, educational environment evaluation may be performed in the framework of several integrated management practices (Table 1).

These management techniques have in common the following features:

- They may all complement each other, since management of a higher school improvement is a complicated multi-level process that requires employing instruments from various disciplines.

- Managers have to collect data for understanding the situation they are operating in, and to "keep all lines of communication in the organization open" (Stoner 1978); information playing a key role in linking different units of the organization (Hallinger, Snidvongs 2008).

- Knowledge is regarded as the most important asset of the 21 st century organization (Gray 2001); knowledge can become a means of the educational environment quality enhancement, especially "change knowledge" (Fullan 2006).

- As stated by Hallinger and Snidvongs (2008), knowledge management is can be successfully used in the context of improvement and change of an educational organisation. Knowledge management is regarded as "strategic and systematic organisation-wide effort to plan, control and deploy resources" intended to sustain learning within the organisation and provide quality services to customers (Gill 2009). So, knowledge management procedures should become the basis of various pedagogical and managerial practices integration in the dynamic process of managing the educational environment. 
- For transferring knowledge across the educational environment we need to establish an efficient system of internal communication based on ICTs (Information and Communication Technologies), which comprises a set of knowledge strategies.

Table 1. Some integrated management practices used to provide quality enhancement of the educational environment

\begin{tabular}{|c|c|}
\hline $\begin{array}{l}\text { Management } \\
\text { practice }\end{array}$ & Key attribute \\
\hline $\begin{array}{l}\text { Total Quality } \\
\text { Management }\end{array}$ & $\begin{array}{l}\text { Managing the educational environment using customer focus by means of } \\
\text { involving students in different quality assurance activities including the educa- } \\
\text { tional environment evaluation }\end{array}$ \\
\hline $\begin{array}{l}\text { Fact-based } \\
\text { Management }\end{array}$ & $\begin{array}{l}\text { Managing the educational environment by means of collecting data from cus- } \\
\text { tomers/students in the form of regular educational environment evaluation, and } \\
\text { using them for performing the fact-based analysis }\end{array}$ \\
\hline $\begin{array}{l}\text { Human Capital } \\
\text { Management }\end{array}$ & $\begin{array}{l}\text { Managing the educational environment by means of collecting and utilising the } \\
\text { intellectual capital through involving students in participative decision-making, } \\
\text { the educational environment evaluation playing an essential role in this process }\end{array}$ \\
\hline $\begin{array}{l}\text { Information } \\
\text { Management }\end{array}$ & $\begin{array}{l}\text { Managing the educational environment by constructing, accumulating and } \\
\text { exchanging collaborative knowledge through creating an efficient system of } \\
\text { internal communication based on ICTs, the educational environment evalua- } \\
\text { tion being one of the basic knowledge transfer schemes in the organisational } \\
\text { communication system }\end{array}$ \\
\hline $\begin{array}{l}\text { Customer } \\
\text { Relationship } \\
\text { Management } \\
\text { (Hallinger, } \\
\text { Snidvongs 2008) }\end{array}$ & $\begin{array}{l}\text { Managing the educational organisation by employing various educational } \\
\text { and managerial instruments aimed at creating a learner-centred educational } \\
\text { environment, regular environment evaluation being a helpful managerial tool } \\
\text { to monitor the quality of educational services }\end{array}$ \\
\hline $\begin{array}{l}\text { Knowledge } \\
\text { Management }\end{array}$ & $\begin{array}{l}\text { Managing the educational environment with the aim to provide knowledge } \\
\text { enhancement of the organisation, regular educational environment evaluation } \\
\text { being a useful tool for developing collaborative knowledge }\end{array}$ \\
\hline
\end{tabular}

We believe that in the framework of integrated management procedures, educational environment evaluation is supposed to be an efficient managerial instrument for monitoring the quality of the educational services provided by a higher education institution.

\section{Educational environment evaluation as part of the strategic analysis process}

We believe that to provide qualitative changes in the educational environment is of primary importance for successful performance of any educational organization. Qualitative changes in the environment must lead to school improvement. Management of higher school improvement includes performing the strategic analysis, which involves internal resource audit and environmental scanning - SWOT (strengths, weaknesses, opportunities and threats) analysis, as well as culture and values (Fiddler 2002). Evaluation is regarded not only as a technical, but as a political activity associated with decision-making (Rossi, Freeman 1993). The educa- 
tional environment evaluation may be regarded as an element of the strategic analysis, since the data education managers collect must be analysed to assess their previous strategy and to identify their future strategy - that is to make the right decisions.

Measurement of quality in the educational environment being a current concern of education managers (Postema, Markham 2001), measurement issues are now receiving enlarged attention among the education research community (Gallardo et al. 2007). According to Postema and Markham (2001), from the point of view of educators it is important to look towards measures of quality that reflect a "realist set of possibilities within a particular educational environment".

Accepting a participative model of school development (Brauckmann, Pashiardis 2010) we regard the educational environment evaluation that involves students' indirect participation in decision-making as one of the most essential quality assurance activities in the framework of the strategic analysis process. It is vital to understand the change from the point of view of participants (Fiddler 2002). Ehlers (2009) emphasises that both educators and students are supposed to perform as "competent quality developers of their own improved educational environment".

\section{Student evaluations from the customer-driven education standpoint}

The increased competition in the higher education marketplace makes universities use more customer-oriented philosophy in delivering their services (Kara, DeShields 2004). To work out an effective strategic plan for a higher school improvement in the customer-driven education context, it is essential to identify who the customers are and what they want; later this information can be transformed into strategies to attain customer satisfaction by means of quality function deployment - QFD (Raharjo et al. 2007). QFD may be used by education managers as a method of transforming user requirements into service quality. To improve the quality of education and student satisfaction QFD principles are now being utilised in many higher education institutions for performing educational research (Raharjo et al. 2007; Ho et al. 2009).

It is acknowledged that educational institutions have several customers: students, staff, faculty, alumni, donors, etc. (Kara, DeShields 2004). Hallinger and Snidvongs (2008) stress that education managers should find the ways to meet or even exceed students' expectations that is to increase customer loyalty. Every customer in higher education perceives educational quality in a different way; it depends on their requirements and needs. Oldfield and Baron (2000) point out that administrators should focus on student perceptions of educational quality. So, service quality in higher education is assessed through the learner's perspective.

According to Hemsley-Brown and Oplatka (2010), a faculty that supports the customeroriented approach would gather information about "the environment, which students inhabit"; it should be "attentive and responsive to their interests and points of view". This way, managers can get their internal customers' perspective about the educational environment quality engaging students in participative decision-making. Using this approach education managers are likely to introduce improvements for future students "based on their anticipated needs" (ibid). Voss (2009) acknowledges that if instructors have enough understanding of 
students' expectations, they could manage them and "bring them to a realistic level"; the information they collect would help in the development of various innovative management and pedagogical tools. This way, the obtained information is utilised for creating a strategy for a higher school improvement.

Knowledge needed for accomplishing educational quality enhancement may be developed by means of employing different knowledge strategies together with regular educational environment evaluation as part of school self-assessment with emphasis on collecting student feedback (Stukalina 2010b). Student evaluations have become popular among educators: they are easy and inexpensive to manage: they give an impression of objectivity, as they produce exact numbers; there are not many alternatives to SEF if you want to assess teaching effectiveness (Huemer 2010). Moreover, most researchers have the same opinion that SEF are "highly reliable, in that students tend to agree with each other in their ratings of an instructor, and that they are at least moderately valid, in that student ratings of course quality correlate positively with other measures of teaching effectiveness" (ibid).

We presume that education managers can successfully employ student evaluations in various contexts - student evaluations of study course, student evaluations of study programme, etc., provided that they are used in the framework of a wide-ranging educational environment evaluation performed as internal resources audit. In the focus of customer-centric (studentcentred) environment is the target audience (students); the educational environment is evaluated by gathering student feedback in the form of student surveys, e.g. student interviews and student questionnaires. In this fashion, we provide students with an opportunity to express their impressions and individual opinions. The students (customers) are supposed to be involved in the discussion of the learning conditions and other related internal conditions in school; they are also expected to participate in the process of decision-making.

The main objective of education managers then becomes "to translate the "voice of students" into management characteristics in order to improve the educational services provided to students" (Varnavas, Soteriou 2002), and to deliver increased value to their customers (Hallinger, Snidvongs 2008) - that is to enhance quality of the educational services provided.

\section{Student satisfaction and student motivation as the result of students' interactions with the educational environment}

We support the general approach to customer satisfaction (Wittingslow, Markham 1999) that highlights the relationship between customers' expectations of services/products and their actual ratings of their satisfaction of those services/products.

As said by Postema and Markham (2001), it was Guolla, who in his work "Assessing the teaching quality to student satisfaction relationship: Applied customer satisfaction research in the classroom", related a customer satisfaction model to student evaluation of teacher performance. We assume that student satisfaction can be related to student evaluation of the quality of the educational environment.

According to Astin (1993), student satisfaction is regarded as a key product of higher education. As said by Harvey (2001), students are considered to be "important stakeholders 
in the quality monitoring and assessment processes". Students' satisfaction can be defined as "a customer's post-consumption evaluation of a service" including "cognitive and affective components" (Chitty, Soutar 2004).

We suggest using the following definition of student satisfaction:

"Student satisfaction, being the result of student interactions with the educational environ-

ment in the form of students' perceptions of the educational environment, is an outcome

of the expectations and experiences of the subject, study course, or study programme as

a requisite element of the integrated educational environment".

Stimulating students' development is one of the main goals of higher education (Astin 1993). There are different ways to achieve this objective, continuously collecting information on student satisfaction being one of them. Measuring student satisfaction with their experience in higher education has become a habit (Douglas et al. 2006). Student satisfaction measurement is used by higher education institutions to predict students' postlearning behaviour (Gallardo et al. 2007).

As stated by Newby and Marcoulides (2008), the eventual outcome of the personenvironment interaction is likely to affect both the person and the performance outcome. In their interactions with the educational environment, students gain new experience in education assessing the educational services provided by the university. We suppose that students' perceptions of their educational environment are significant for determining their level of satisfaction.

Universities may employ student satisfaction data to better understand and improve their educational environment with the aim to increase retention rates that is to manage the university retention process. According to Douglas et al. (2006), "keeping customers satisfied is what leads to customer loyalty"; managing the retention process is an important issue for modern universities. Nowadays, successful higher educational institutions focus on their students' requirements and expectations; they utilize student satisfaction data as an indicator of how efficiently they provide what learners "expect, need and want" (Low 2000). According to Voss et al. (2010), "positive perceptions of service quality can result in student satisfaction"; satisfied students may want to take further courses at the same university. University student satisfaction is regarded as a significant component in "attracting and retaining high achievers", who consecutively enlarge the reputation and status of the university"; from an institutional point of view, satisfied students are "more likely to continue in their studies and are more likely to succeed academically" (Wikiversity: Web source).

The research conducted by Elliott and Shin (Voss et al. 2010) showed that student satisfaction has positive impact on student motivation. We suppose that motivation can be associated with students' positive emotional experience in education. Motivation "involves psychological processes that bring about an individual's desire and intentions to behave in a particular way" (Estrella 2007). And this is the environment created throughout an entire educational institution that cultivates the motivation to learn - to obtain new knowledge (Renchler 1992).

So, satisfaction is supposed to be closely related to motivation; in other words, with students' post-learning behaviour - the intention to continue their studies. Being responsive to our students' requirements and expectations, we are also supposed to increase their motiva- 
tion for further studies. We believe that student satisfaction can be viewed as a precursor of student motivation.

We suggest using the following definition of student motivation:

"Student motivation, being associated with students' positive emotional experience in education as the result of students' interactions with the educational environment in the form of student perceptions of the educational environment, is a student's eagerness to actively participate in the new knowledge-gaining activities".

Therefore, student satisfaction and student motivation can be regarded as the result of student interactions with the educational environment in the form of students' perceptions of the environment (Stukalina 2011).

Understanding the main dimensions of student satisfaction and the factors that influence student satisfaction has a few potential benefits and applications for both institutions and students (Wikiversity: Web source). Not by chance many studies were dedicated to analyzing the factors having their impact on university student satisfaction. The study performed by Wiers-Jenssen et al. (2002), shows that the most important determinants of student satisfaction are the academic and pedagogic quality of teaching. Other researchers mention the following factors: student centeredness, the social climate and instructional effectiveness (Elliott, Healy 2001), course content and social aspects (Garcia-Aracil 2008).

Thus, student satisfaction is supposed to be inspired by various aspects of the educational environment; these aspects being related to different organizational processes and the results of the organization's operation. Learners' assessment of the educational environment quality can serve as an efficient mechanism employed for generating evaluative information about the basic aspects of the environment. Besides, according to Hutchinson (2003), assessments themselves are typically "a strong intrinsic motivator for learners".

We assume that student satisfaction and student motivation should be analysed in the framework of a methodical educational environment evaluation, which, in turn, is performed in the context of a wide-ranging model of managing the educational environment as an integrated multi-level supersystem.

\section{Creating the system of managerial and pedagogical support in the framework of quality assurance in education}

To revise the existing educational provision education managers should collect relevant information for discussing and improving the quality of educational services. Several instruments for this work are included in the quality assurance system, the most important goal of the quality assurance system being that all courses and programs should be assessed.

The learner-centred educational environment evaluation scheme should take into account students' perceptions about the quality of the educational services provided by the university. It is based on seeking constructive feedback from students for creating a learner-centred educational environment. In the complex scheme of the educational environment evaluation, with emphasis on student satisfaction and student motivation, the main activities for quality development involve (among other things, which are not considered in this paper) regular 
student surveys. The surveys include an assortment of predefined questions and responses to choose from as a means of

a) generating diagnostic data for assessing the quality of the educational environment;

b) tracking the implementation of central quality improvement activities in relation to each course and every programme.

Student surveys as part of the educational environment evaluation is a vital quality assurance activity aimed at assessing the quality of educational services; they assist education managers

- to assure the quality of educational services;

- to provide individual teachers with information to help them in their professional development;

- to provide students with information about responses to student evaluation data.

It is desirable that previous to any survey being undertaken, students ought to be advised of the purpose of the survey, what people will have admission to the survey data and the reports to be generated from the data. The surveys address different objectives and may range from post-course evaluation surveys to all-embracing surveys including a variety of factors to be assessed. But in any case, the educational environment must be evaluated as integrated whole; and all four basic aspects of the educational environment must be incorporated in the learner-centred educational environment evaluation model for assessment.

We suppose that student satisfaction and student motivation should be included in the survey as autonomous issues to be analysed. This way, we will be able to investigate the relationship between student satisfaction/student motivation (on the one hand) and various important factors associated with the fundamental aspects of the environment (on the other hand), which might to a certain degree influence student satisfaction/student motivation, e.g. the quality and availability of teaching materials, the study course content, the environment safety and comfort, the computer laboratory facilities, etc. These factors may serve as evaluation indicators of the educational environment quality measurement - the parameters used to assess the environment's quality. If unsatisfactory quality is identified in one of the areas under inspection, the goal of the quality assurance system is to improve the situation. For this purpose, applying a set of generated diagnostic data we need to establish the system of managerial and pedagogical support aimed at enhancing the quality of the educational environment. This system would include a range of integrated management practices based on knowledge management tools as a platform of their integration, and an assortment of innovative pedagogical instruments based on the constructivist approach to education (Fig. 1).

Therefore, higher education institutions employ regular student surveys focused on determining the basic factors that influence student satisfaction/motivation as part of the all-embracing model of the educational environment evaluation to figure out where and how they can improve the quality of the provided educational services. Students can also learn from such surveys; they can help them assess whether a particular university offers the kinds of experiences and opportunities that are supposed to benefit students. 


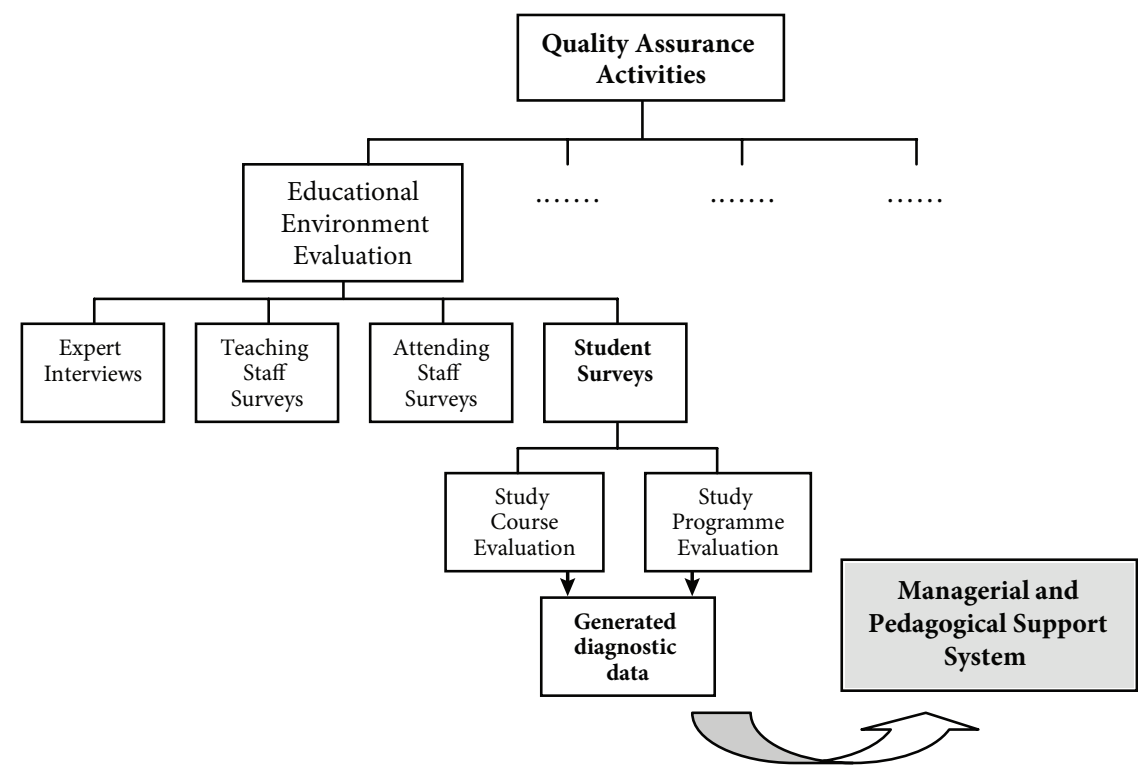

Fig. 1. Creating a system of managerial and pedagogical support in the framework of Quality Assurance in education

\section{Conclusions}

The present paper has discussed the significance of utilizing systematic educational environment evaluation, involving student's indirect participation in decision-making, as one of the most crucial quality assurance activities associated with higher school improvement. We have considered the educational environment evaluation from the customer-driven education viewpoint putting emphasis on the fact that the educational environment is a complex multi-level super system, which needs to be assessed as an integrated whole in the context of a wide-ranging model of managing the educational environment.

The necessity to be responsive to students' needs has forced European higher education institutions to use customer-oriented approach in delivering their services. The satisfaction students receive from their studies is of great importance. In the educational context, it is vital to analyse the relationship between students' expectations of educational services and their actual ratings of their satisfaction of those services. Satisfaction is supposed to be closely related to motivation - that is with the intention to continue their studies to obtain new knowledge. Thus, higher education institutions may employ student satisfaction data to better understand and improve their educational environment with the aim to increase retention rates that is to manage the university retention process.

Student satisfaction is supposed to be inspired by various aspects of the educational environment; these aspects being related to different organisational processes and the results of the organisation's operation. A thorough educational environment evaluation would help academic administrators to examine the relationship between student satisfaction/student motivation and various factors associated with the four fundamental aspects of the environ- 
ment, which might to a certain degree affect student satisfaction/motivation. We suppose that learners' assessment of the educational environment quality can serve as an efficient instrument used for generating evaluative information necessary for developing a proper strategy for higher school improvement and creating the system of managerial and pedagogical support aimed at enhancing the quality of the educational environment.

This work has been supported by the European Social Fund within the project «Support for Doctoral Studies at University of Latvia».

\section{References}

Astin, A. W. 1993. What Matters in College? Four Critical Years Revisited. San-Francisco: Jossey-Bass.

Bologna declaration of 19 June 1999 [cited 10 July 2010]. Available from Internet: http://www.ond.vlaanderen.be/hogeronderwijs/Bologna/documents/MDC/BOLOGNA_DECLARATION1.pdf

Brauckmann, S.; Pashiardis, P. 2010. The clash of evaluations: in search of the missing link between school accountability and school improvement - experiences from Cyprus, International Journal of Educational Management 24(4): 330-350. http://dx.doi.org/10.1108/09513541011045263

Brochado, A. 2009. Comparing alternative instruments to measure service quality in higher education, Quality Assurance in Education 17(2): 74-190. http://dx.doi.org/10.1108/09684880910951381

Chitty, B.; Soutar, G. N. 2004. Is the ECSI model applicable to tertiary education?, in Proceedings of 2004 ANZMAC Conference, Wellington, New Zealand [cited 12 April 2010]. Available from Internet: http://smib.vuw.ac.nz:8081/WWW/ANZMAC2004/CDsite/papers/Chitty1.PDF

Diamantis, G. V.; Benos, V. K. 2007. Measuring student satisfaction with their studies in an international and European studies department, Operational Research an International Journal 7(1): 47-59.

Douglas, J.; Douglas, A.; Barnes, B. 2006. Measuring student satisfaction at a UK university, Quality Assurance in Education 14(3): 251-267. http://dx.doi.org/10.1108/09684880610678568

Ehlers, U. D. 2009. Understanding quality culture, Quality Assurance in Education 17(4): 343-363. http://dx.doi.org/10.1108/09684880910992322

Elliott, K. M.; Healy, M. A. 2001. Key factors influencing student satisfaction related to recruitment and retention, Journal of Marketing for Higher Education 10(4): 1-11. http://dx.doi.org/10.1300/J050v10n04_01

Estrella, J. 2007. Leadership in the classroom: closing the achievement gap through motivation, Honors College Theses. Paper 51 [cited 8 November 2010]. Available from Internet: http://digitalcommons. pace.edu/honorscollege_theses/51

Fiddler, B. 2002. Strategic Management for School Development: Leading Your School's Improvement Strategy. London, SAGE Publications.

Fullan, M. 2006. Change theory: a force for school improvement. Seminar Series Paper No. 157, November 2006. Centre for Strategic Education [cited 15 November 2010]. Available from Internet: http://www. michaelfullan.ca/Articles_06/06_change_theory.pdf

Gallardo, S.; Barrero, F. J.; Rocio Martinez Torres, M.; Toral, S. L.; Duran, M. J. 2007. Addressing learner satisfaction outcomes in electronic instrumentation and measurement laboratory course organization, IEEE Transactions on Education 50(2): 129-136.

http://dx.doi.org/10.1109/TE.2007.893173

Garcia-Aracil, A. 2008. European graduates' level of satisfaction with higher education, Higher Education 57: 1-21. http://dx.doi.org/10.1007/s10734-008-9121-9 
Gill, A. 2009. Knowledge management initiatives at a small University, International Journal of Educational Management 23(7): 604-616. http://dx.doi.org/10.1108/09513540910990834

Gray, P. H. 2001. A problem-solving perspective on knowledge management practices, Decision Support Systems 31(1): 87-102. http://dx.doi.org/10.1016/S0167-9236(00)00121-4

Greenfield, T. B. 2004. Theory and organisation: a new perspective and its implications for schools, in Tomlison, H. (Ed.). Educational Management: Major Themes in Education, Educational Values, vol. 1. London, New York, RoutledgeFalmer, 71-94.

Hallinger P.; Snidvongs, K. 2008. Educating leaders: is there anything to learn from business management?, Educational Management Administration and Leadership 36: 9-31. http://dx.doi.org/10.1177/1741143207084058

Harvey, L. 2001. Student Feedback: A Report to the Higher Education Funding Council for England. Centre for Research into Quality, The University of Central England in Birmingham, Perry Barr, Birmingham [cited 1 June 2011]. Available from Internet: http://www0.bcu.ac.uk/crq/publications/ studentfeedback.pdf

Harvey, L. 2004-2009. Analytic Quality Glossary, Quality Research International [cited 17 December 2010]. Available from Internet: http://www.qualityresearchinternational.com/glossary

Hemsley-Brown, J.; Oplatka, I. 2010. Market orientation in universities. A comparative study of two national higher education systems, International Journal of Educational Management 24(3): 204-220. http://dx.doi.org/10.1108/09513541011031565

Ho, W.; Higson, H. E.; Dey, P. K.; Xiaowei, Xu; Bahsoon, R. 2009. Measuring performance of virtual learning environment system in higher education, Quality Assurance in Education 17(1): 6-29. http://dx.doi.org/10.1108/09684880910929908

Huemer, M. 2010. Student evaluations: a critical review [cited 30 August 2010]. Available from Internet: http://home.sprynet.com/ owl1/sef.htm

Hutchinson, L. 2003. Educational Environment. Clinical Review: ABC of Learning and Teaching [cited 14 June 2010]. Available from Internet: htpp://bmj.com/cgi/content/full/326/7393/810

Kara, A.; DeShields, O. W. 2004. Business student satisfaction, intentions and retention in higher education: an empirical investigation, $M E Q$, vol. 3, Fall 2004 [cited 15 November 2010]. Available from Internet: http://www.marketingpower.com/Community/ARC/gated/Documents/Teaching/MEO/ student_satisfaction.pdf

Low, L. 2000. Are college students satisfied? A National Analysis of Changing Expectations. The USA Group Foundation New Agenda Series ${ }^{\mathrm{mw}}$, Indianapolis, USA Group, Inc. [cited 1 June 2011]. Available from Internet: http://www.learningoutcomeassessment.org/documents/SSI-AreCollegeStudentsSatisfied.pdf

McRoy, I.; Gibbs, P. 2009. Leading change in higher education, Educational Management Administration and Leadership 37(5): 687-704.

Newby, M.; Marcoulides, L. D. 2008. Examining student outcomes in university computer laboratory environment: issues for educational management, International Journal of Educational Management 22(5): 371-385.

Oldfield, B. M.; Baron, S. 2000. Student perceptions of service quality in a UK University business and management faculty, Quality Assurance in Education 8(2): 85-95.

Postema, M.; Markham, S. 2001. Student satisfaction: a method for exploring quality factors within, in Proceedings of NACCQ, New Zealand, July 2001, 113-120.

Raharjo, H.; Xie, M.; Goh, T. N.; Brombacher, A. C. 2007. A methodology to improve higher education quality using the quality function deployment and analytic hierarchy process, Total Quality Management and Business Excellence 18(10): 1097-1115. 
Renchler, R. 1992. Student motivation, school culture, and academic achievement: what School Leaders Can Do. Trends \& Issues: A series of papers highlighting recent developments in research and practice in educational management. University of Oregon.

Rossi, P. H.; Freeman, H. E. 1993. Evaluation: A Systematic Approach. 5th edition. London: Age publications.

Standards and Guidelines for Quality Assurance in the European Higher Education Area. 2005. European Association for Quality Assurance in Higher Education, 2005, Helsinki, Finland [cited 12 June 2010]. Available from Internet: http://www.bologna-bergen2005.no/Docs/00-Main_doc/050221_ENQA_report.pdf

Stoner, J. A. F. 1978. Management. Englewood Cliffs, N.J.: Prentice-Hall, Inc.

Stukalina, Y. 2011. Addressing student satisfaction and student motivation in the ESP course organization in the framework of creating a student-centered educational environment, in Proceedings of the 3rd Paris International Conference on Education, Economy and Society. Ed. Prof. Guy Tchibozo. Paris, 553-565.

Stukalina, Y. 2008. How to prepare students for productive and satisfying careers in the knowledge-based economy: creating more efficient educational environment, Technological and Economic Development of Economy 14(2): 197-207. http://dx.doi.org/10.3846/1392-8619.2008.14.197-207

Stukalina, Y. 2010a. Using quality management procedures in education: managing the learner-centred educational environment, Technological and Economic Development of Economy 16(1): 75-93. http://dx.doi.org/10.3846/tede.2010.05

Stukalina, Y. 2010b. Management of the educational environment: developing a strategy for school improvement, in Proceedings of the 2nd Paris International Conference on Education, Economy and Society. Ed. Prof. Guy Tchibozo. Vol. 1. Refereed Papers. Paris, 428-440.

The Research Methods Knowledge Base [cited 21 November 2010]. Available from Internet: http://www.socialresearchmethods.net/kb/index.php American Evaluation association

Varnavas, A. P.; Soteriou, A. C. 2002. Towards customer-driven management in hospitality education: a case study of the higher hotel institute, Cyprus, International Journal of Educational Management 16(2): 66-74.

Voss, R. 2009. The experience of students in German college education, Quality Assurance in Education 17(2): 156-173.

Voss, R.; Gruber, T.; Reppel, A. 2010. Which classroom service encounters make students happy or unhappy? Insights from an online CIT study, International Journal of Educational Management 24(7): 615-636.

Wiers-Jenssen, J.; Stensaker, B.; Grøgaard, J. B. 2002. Student satisfaction: towards an empirical deconstruction of the concept, Quality in Higher Education 8(2): 183-195.

Wikiversity [cited 11 November 2010]. Available from Internet: http://www.wikiversity.org

Wittingslow, G. W.; Markham, S. J. 1999. Customer-driven model of satisfaction behaviour, Australasian Journal of Market Research 7(2): 29-38.

Yulia STUKALINA. MSc. Paed., Assistant Professor, Chair of Linguistics, Transport and Telecommunication Institute (Riga, Latvia). University studies: First degree in foreign languages, Latvian State University, Faculty of Foreign Languages (1987). Master's Degree in Pedagogics (1996). PhD student, Faculty of Education and Psychology, University of Latvia. Research interests: Educational management, Pedagogics, Linguistics. 